\title{
MICROWAVE ASSISTS HYDROTHERMAL SYNTHESIS OF SOME NANOPARTICLES FOR TARGETED NONINVASIVE OF MALIGNANT CELLS IN GENITAL SYSTEM CAUSING TESTICULAR TUMORS IN MICE
}

\author{
FATHI, A. ${ }^{1}$; MONA, M. SOBHY ${ }^{2}$; ALMUHAMMADY, A. ${ }^{2}$; MERIHAN, E. ALI ${ }^{4}$ \\ AND SHEREIN, MAHMOUD ${ }^{5}$ \\ ${ }^{1}$ Immunity Unit, Animal Reprod. Res. Inst. ARC, Agriculture Research Center, Giza, Egypt. \\ ${ }^{2}$ Reproductive Diseases Dept., Animal Reprod. Res. Inst. ARC, Agriculture Research Center, Giza, Egypt. \\ ${ }^{3}$ Arab Centers for Nanotechnology, Cairo University \\ ${ }^{4}$ Pathology Dept. Fac. of Vet. Med. Cairo Univ. Giza, Egypt. \\ ${ }^{5}$ Pharmacists in National Cancer Institute, Cairo Univ. El-Kasr El-Ainy
}

Received: 26 July 2020; Accepted: 31 August 2020

\begin{abstract}
Testicular tumors are the prevailing tumor in male of animals, accounting for about $90 \%$ of all tumors affecting the genitalia. Copper nanoparticles ( $\mathrm{Cu} \mathrm{NPs)}$ are emerging as promising agents for cancer therapy. The aim of this work was developed of tumors formed in the testis of mice, by exposure to arsenite $\left(\mathrm{As}^{3}\right)$ in drinking water for about 6 months and treated by Copper nanoparticles. Twenty male albino Wister mice with average body weight $100 \mathrm{~g}$ were used and divided into four groups (five mice / group). Group 1 as control negative group; Gp. 2 (tumor group) injected I/V by Sodium arsenite $(0.5 \mathrm{mg} / \mathrm{kg})$ mice once/week for 20 weeks. Gp. 3 (treatment group) gave (Cu NPs.+ Chemotherapy protocol" Etopsoide, Cisplatin and Bleomycin" every 3 weeks and repeated 3 times; Gp. 4 (chemotherapy group) without $\mathrm{Cu}$ NPs. Tissue samples of testis were collected and fixed neutral formalin buffer for histopathology. In the testis of Gp.1 (control group) the seminiferous tubules have the active stages of spermatogenesis with intact germinal epithelium. In Group 2 (tumor Gp.) testicular tumor was formed large yellowish white mass of tumor with hemorrhagic area while in the histopathological examination, testis converted into solid sheet of undifferentiated anaplastic cells showing malignancy with focal areas of necrosis. Gp. 3 (treatment with $\mathrm{Cu}$ NPs. + Chemotherapy) was noticed markedly reduce histopathological changes at which the testis appeared neared to normal pattern and active spermatogenesis increased in most of seminiferous tubules as well as restoration of germinal epithelium. Also, interstitial edema was decreased with minimal injury of testicular tissue. Gp.4 chemotherapy treated group, there was no evidence of anaplastic cells; seminiferous tubules showed testicular degeneration with no active spermatogenesis, presence of spermatid giant cells and spermatid coagulum in addition to testicular edema. Finally, nanomaterial will be reduce the toxicity of chemotherapeutics and increase their effectiveness. We need further studies to establish other types of tumors in animals.
\end{abstract}

Key words: Testicular tumor, Copper nanoparticles, Chemotherapy, mice.

Corresponding author: Mona, M. Sobhy

E-mail address: monagabr17@yahoo.com

Present address: Reproductive Diseases Dept., Animal Reprod. Res. Inst. ARC, Giza, Egypt. 


\section{INTRODUCTION}

Testicular tumors are the prevailing tumor in male, accounting for about $90 \%$ of all tumors affecting the genitalia (Cotchin, 1959). The major types of testicular tumor in pets are sex cord stromal tumors, germ cell tumors, and mixed germ cell sex-cord stromal tumors (Kennedy, et al., 1998). The most common of testicular tumors are Sertoli cell tumors (SCTs) and interstitial cell tumors (ICTs) in sex cord-stromal tumors, seminomas (SEMs) in germ cell tumors (Pinard, 2018).

Tumors are descended, or scrotal, testicles usually benign while those still located in the abdomen to be malignant. Testicles retained in the abdomen are predisposed to Sertoli cell tumors, seminomas and may spread to lymph nodes (Lipowitz, et al., 1973). Testicular tumors produce excessive hormones such as estrogen or testosterone. Sertoli cell tumors have a higher rate of spread than other testicular tumors. Males affected with these tumors show swelling of the testicular or scrotal area (Grootenhuis et al., 1990).

The known cause of testicular cancer seem to be caused by a complex mix of risk factors, some environmental and some genetic or hereditary (Kawakami et al., 2007). The prognosis for testicular tumors that have spread is varies greatly depending on the location, type of tumor and treatment options. The most commonly recommended treatment is surgical removal of the testicles, chemotherapy and/or radiation therapy may be considered. All three methods risk damage to normal tissues or incomplete eradication of the cancer (Stewart, 2017).

The application of nanotechnology the field of study has advanced rapidly in recent years. Nanoparticles are emerging as promising agents for cancer therapy and are being investigated as drug carriers. In medicine, most interest is in the use of nanoparticles to enhance drug delivery with interest also in in vitro diagnostics, novel biomaterial design, bio imaging, therapies and active implants (Magrez et al., 2006).

Due to wide applications of noble metal nanoparticles, copper is gaining application in the fields of medicines, optics, electronics and antimicrobial (Gawande et al., 2016). However, copper is cheaper than silver, readily miscible with polymers, and relatively stable chemically and physically. (Ahmed et al., 2016). In recent years, copper has been used as a building material for hospitals and medical centers as its antimicrobial properties proved useful in the fight against infections (Snchez-Sanhueza et al., 2016). Copper nanoparticles have potential to be used in cancer therapy, due to their properties and cytotoxic effect in cancer cells (Wozniak, 2016).

Nanotechnology cancer therapy extends beyond drug delivery into the creation of new therapeutics available only through use of nanomaterial properties (Bertrand et al., 2014). The physical properties of nanoparticles, such as energy absorption and re-radiation, can also be used to disrupt diseased tissue, as in laser ablation and hyperthermia applications (Maeda et al., 2013).

Inorganic arsenic is a component of the Earth's crust found on the surface of rocks or in complex with metals. The transport and distribution of arsenic in the environment is due to the chemical forms in which it occurs, with different forms of arsenic in water, soil, and air (Chilvers and Peterson 1987). The exposure to inorganic arsenite with the major route of drinking water intake will be increased incidence of skin carcinoma in areas where the water is naturally enriched with arsenic the form of squamous cell carcinoma (Martínez et al., 2012).

Sodium arsenite $\left(\mathrm{As}^{3+}\right)$ is the most extensively arsenic compound. In animals causes oxidative stress through the generation of reactive oxygen (Xu et al., 2012) and is associated with chromosomal 
abnormalities from oxidative DNA damage (Matsui et al., 1999) and carcinogenesis (Mehata et al., 2003).

The carcinogenicity of arsenic in animals has a long latency period for the development of neoplastic. Early in vivo work on rats and mice were performed with as supplementation of the diet or water supply in the range of 2 to $250 \mathrm{mg}$ as/L (Blakeley 1987).

The aim of this work was developed of tumors formed in the testis of mice, by chronic exposure to different doses of $\mathrm{As}^{3+}$ in drinking water for varying periods of time. The influence of $\mathrm{As}^{3+}$ on the health status of the animals and on the formation, development, and malignant transformation of tumors was also evaluated. Then introduces copper nanoparticle with a focus on recent led to treatment of testicular tumors.

\section{MATERIALS AND METHODS}

\section{Animals:}

Twenty male albino Wistar mice with average body weight $100 \mathrm{~g}$ were used. The animals were housed in plastic cages at room temperature $25-27 \mathrm{C}^{\circ}$, and relative humidity $50-60 \%$. Rats had free access to water and maintenance ration. This study was performed in accordance with the Institutional Animal Use and Care Committee (IACUC) guidelines, Cairo University.

Sodium arsenite $\left(A s^{3}\right)$ :

Sodium arsenite $\left(\mathrm{As}^{3}\right)$ was obtained from National Cancer Institute, Cairo Univ. Inorganic Sodium arsenate (As) "Define
Chem Company, India" is proven as carcinogenic to mammals, $(0.5 \mathrm{mg} / \mathrm{kg})$ injection $\mathrm{I} / \mathrm{V}$ in mice.

\section{Copper nanoparticle:}

Copper nanoparticles were kindly obtained from Dr. Abdel Salam Almuhammady worked in Arab Center for Nanotechnology, Cairo University. The copper nanoparticles were characterized by UV-visible spectrophotometer, FTIR, X-ray diffraction, scanning electron microscope (Hitachi S2150, Krefeld, Germany). The nanoparticles were sterilized using a filter with holes of 0.22 micrometer diameter (Thamer \& Barakat, 2019).

\section{Experimental design:}

Twenty mice were divided into four groups (five mice / group).

Group 1: Control negative group was injected by $0.5 \mathrm{ml} / \mathrm{Kg}$ saline solution once/week for 20 weeks and observed till the end of experiment.

Group 2: Tumor group was injected intravenously by Sodium arsenite at a dose of $(0.5 \mathrm{mg} / \mathrm{kg})$ mice once/week for 20 weeks.

Group 3: Treatment group (Copper nanoparticles $0.35 \mu \mathrm{g} / \mathrm{ml}+$ Chemotherapy) was given in the same time every 3 weeks and repeated 3 times, the chemotherapy included its protocol was described in table (1).

Group 4: Chemotherapy group without copper nanoparticles, its protocol was described in table (1).

Table 1: The protocol of Chemotherapy

\begin{tabular}{cccc}
\hline Chemotherapy & Dose & Infusion & Duration \\
\hline Etopsoide* $^{*}$ & $100 \mathrm{mg} / \mathrm{m}^{2}$ & $1 \mathrm{hr}$. infusion & $1^{\text {st }}$ day $\& 5^{\text {th }}$ day \\
\hline Cisplatin* $^{*}$ Bleomycin* & $20 \mathrm{mg} / \mathrm{m}^{2}$ & $2 \mathrm{hr}$. infusion & $1^{\text {st }}$ day $\& 5^{\text {th }}$ day \\
\hline 30 Units & I/V & $1^{\text {st }}$ day, $8^{\text {th }} \& 15^{\text {th }}$ day. \\
\hline
\end{tabular}

*: Manufacture by Thymoorgan Pharmazie, GMBH, Germany. 


\section{Histopathology:}

Tissue samples of testis were collected and fixed in $\mathbf{1 0} \%$ neutral formalin buffer. After fixation, tissues were processed by paraffin embedding technique and sectioned by microtome (Leica 2135, Germany) at $3 \mu \mathrm{m}$ thick sections. Tissue sections were then stained by hematoxylin and eosin stain and examined by light microscope (Olympus XC30, Tokyo, Japan). Lesions were photographed by digital Camera (Olympus XC30, Tokyo, Japan).

\section{RESULTS}

\section{Macroscopic findings:}

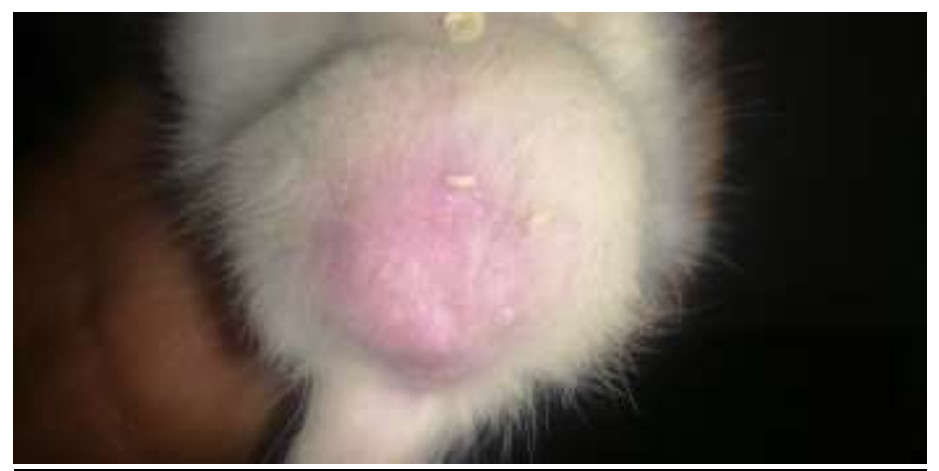

Fig. 1: Tumor group was injected intravenously by Sodium arsenite with enlarged testis.

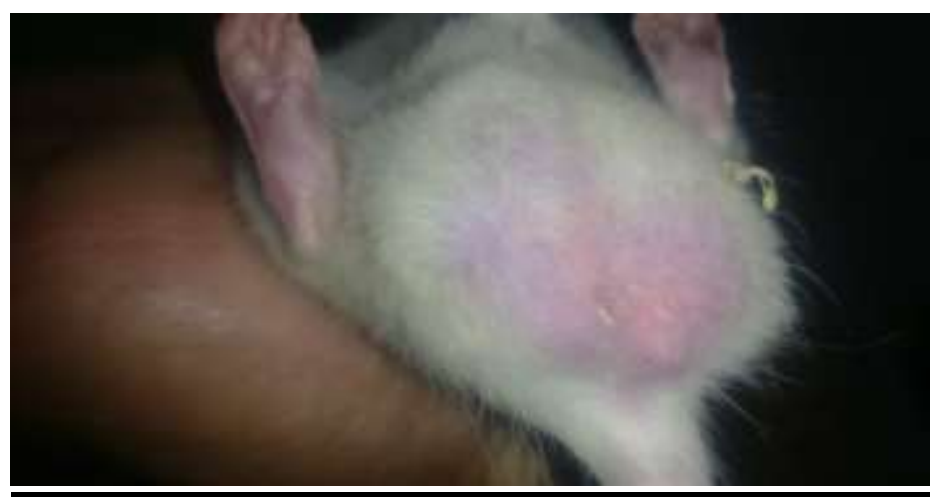

Fig. 2: Chemotherapy group without $\mathrm{Cu}$ NPs showed mild congestion in the left testis.

\section{Histopathological results}

In the testis of Gp.1 (control group) the seminiferous tubules have the active stages of spermatogenesis including
Spermatogonia, spermatocytes and spermatozoa with intact germinal epithelium as shown in (Fig.3).

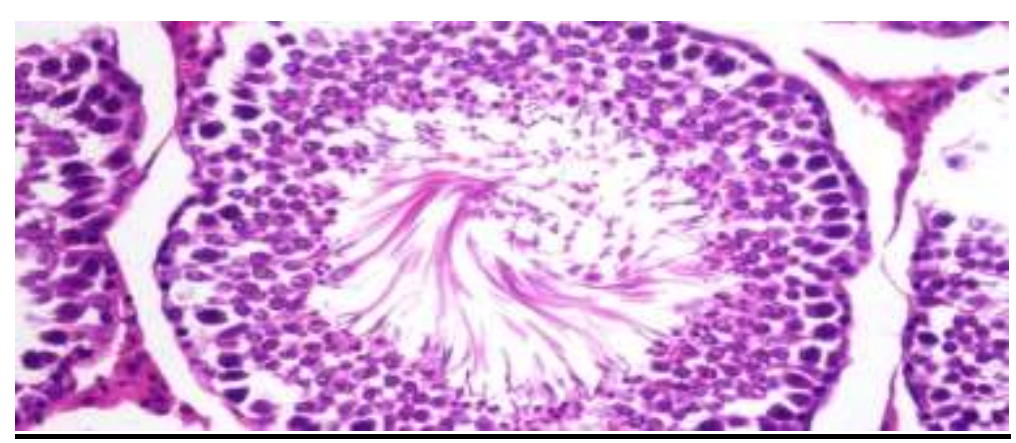

Fig. 3: Testis of Gp. 1 control Gp. showing well-structured features including normal spermatogonial cell layers and normal spermatogenesis. 


\section{Tumor group:}

In Group 2 (Tumor Gp.) the testis of sodium arsenite administrated group, testis were converted into solid sheet of undifferentiated anaplastic cells showing criteria of malignancy altered with focal areas of necrosis as shown in (Fig. 4, 5 \&6).

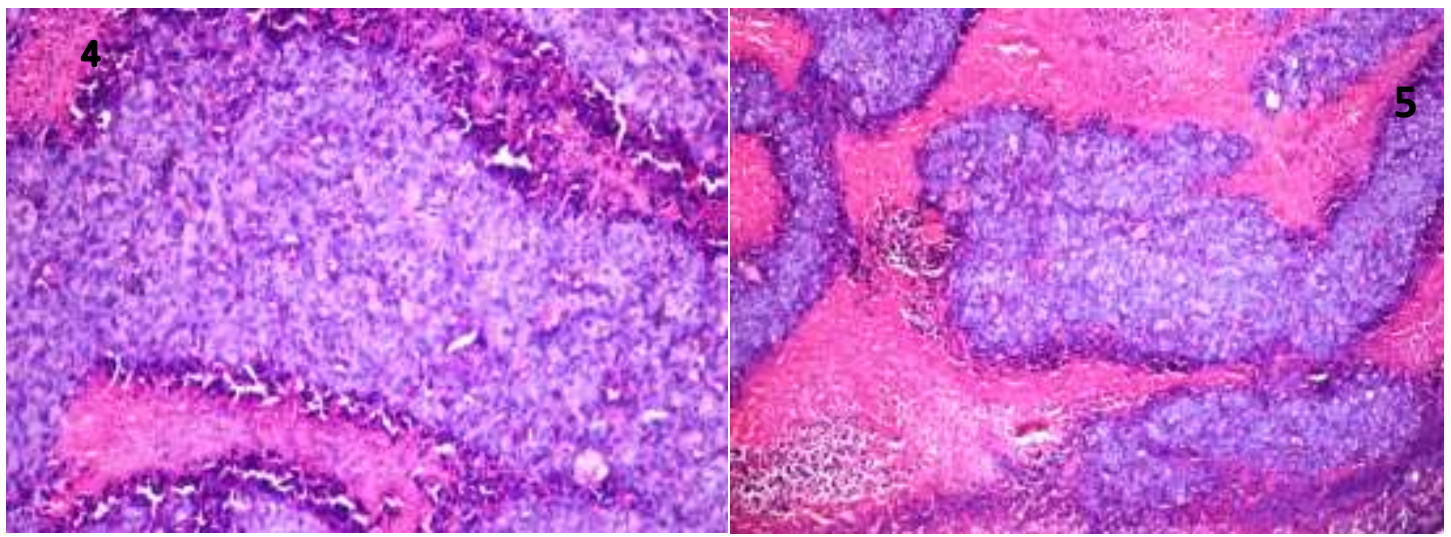

Fig.4 \&5: Gp. 2 solid sheet of undifferentiated anaplastic cells showing criteria of malignancy (hyperchromacia, mitotic figure, and pleomorphism) altered with focal areas of necrosis.

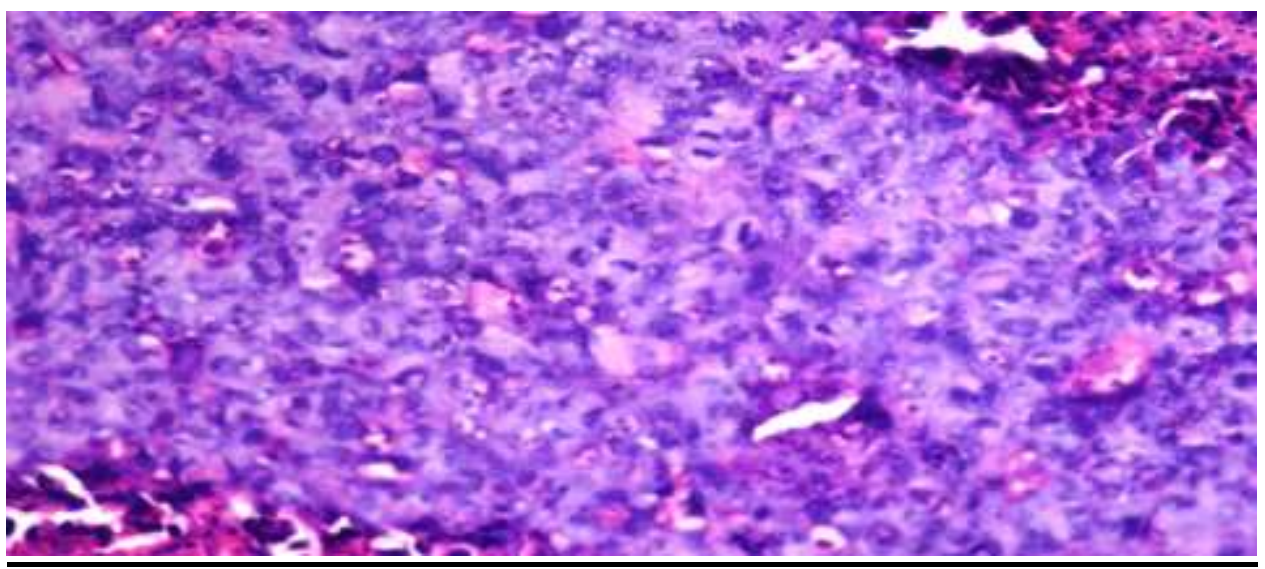

Fig.6: Gp.2 tumor Gp. demonstrated the high mitotic index of anaplastic cells.

\section{Group 3: Treatment with Chemotherapy and copper nanoparticles}

In the testis of chemotherapy and copper nanoparticles treated group, it was noticed that they could markedly reduce the sodium arsenite induced histopathological changes at which the testis appeared neared to normal pattern as shown in (Fig.7, 8, 9 and 10) in which the active spermatogenesis was increased in most of seminiferous tubules but the lumen still free of spermatozoa in some seminiferous tubules as well as restoration of germinal epithelium with only few not intact spaces. The interstitial edema was decreased and histology showed minimal injury of testicular tissue. 


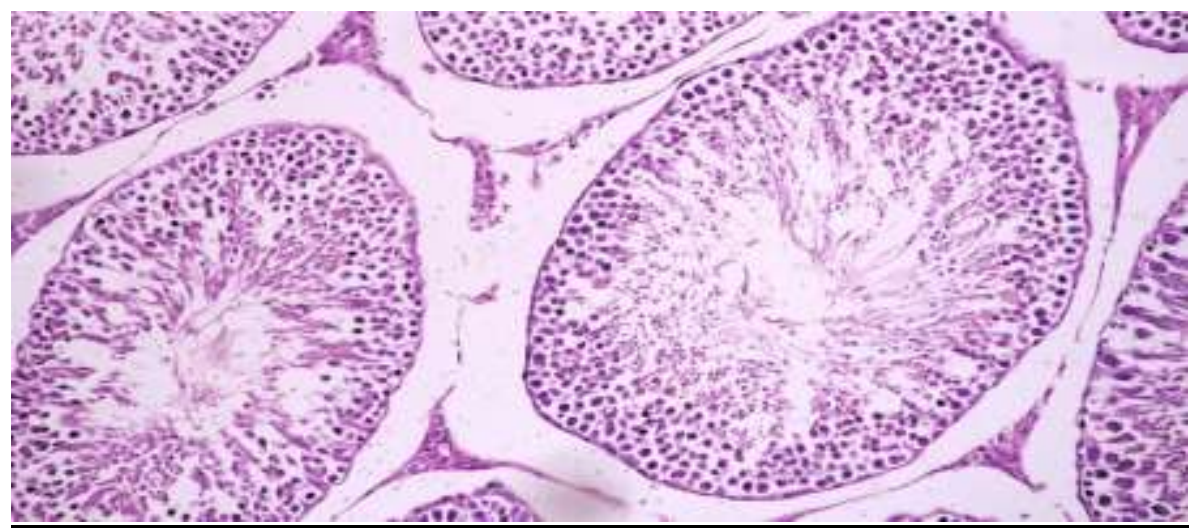

Fig.7: Testis of Gp. 3 treated mice showing well organized seminiferous tubules with spermatogenic cycle.

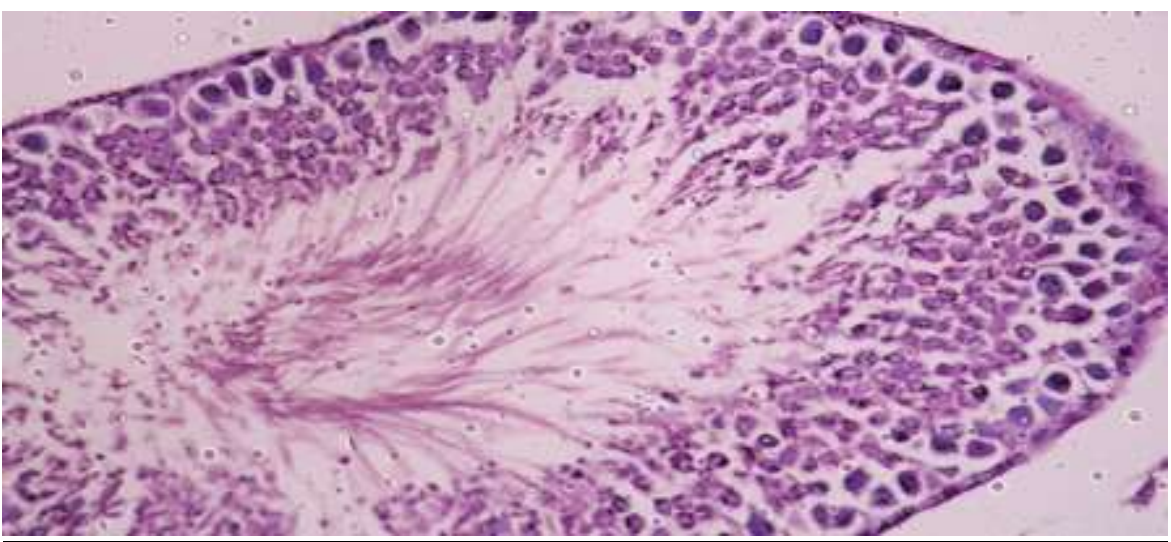

Fig.8: Testis of Gp. 3 treated group showing restored spermatogenic cycle with presence of spermatozoa in the lumen of seminiferous tubules.

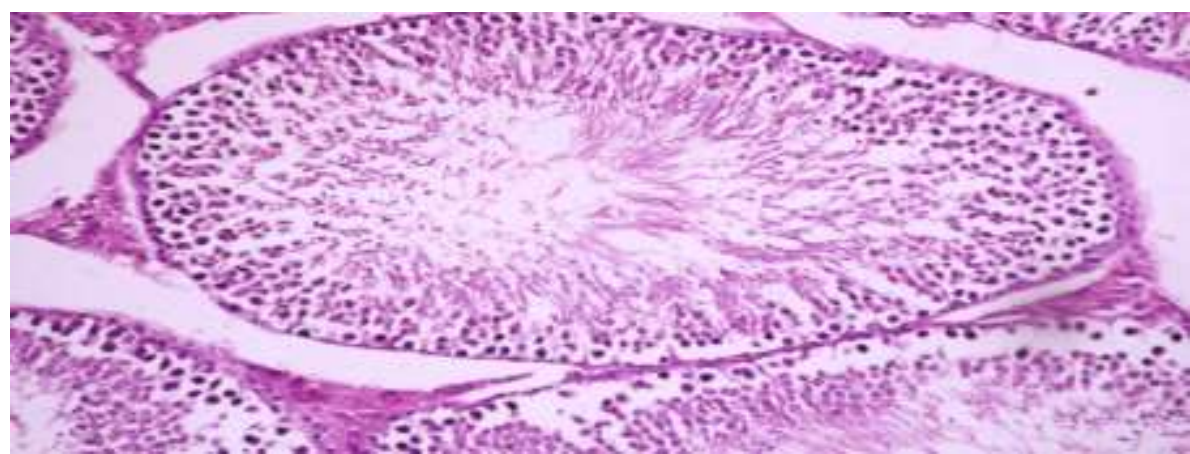

Fig.9. Testis of Gp.3 treated group showing restoration of spermatogenic series.

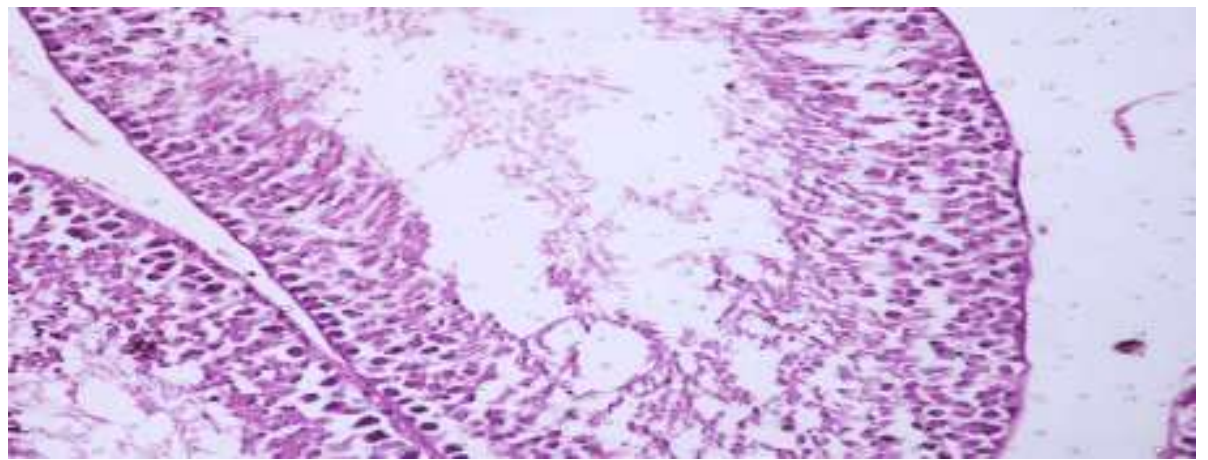

Fig.10: Testis of Gp.3 showing restoration of spermatogenic cell layer lumen free of spermatozoa. 


\section{Group 4 treatment with Chemotherapy} alone

In the testis of chemotherapy alone treated group, there was no evidence of anaplastic cells. The seminiferous tubules showed testicular degeneration with no active spermatogenesis (Fig.11) with presence of spermatid giant cells (Fig.12) and spermatid coagulum in some seminiferous tubules (Fig.13) in addition to testicular edema (Fig. $14 \& 15)$.

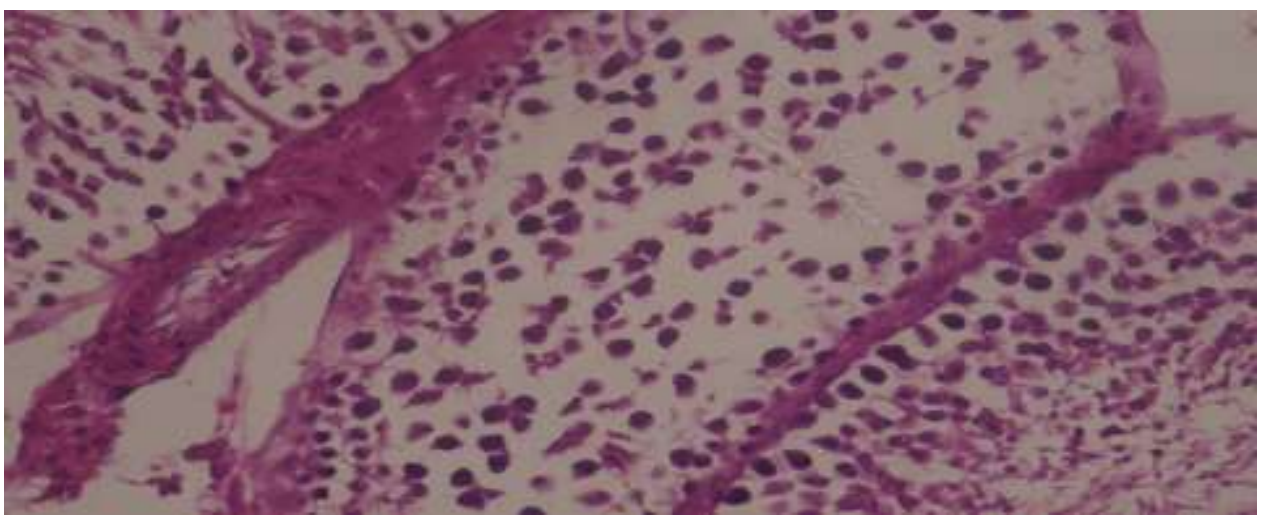

Fig.11: Testis of Gp.4 chemotherapy administrated group showing complete destruction of spermatogonial cell layers.

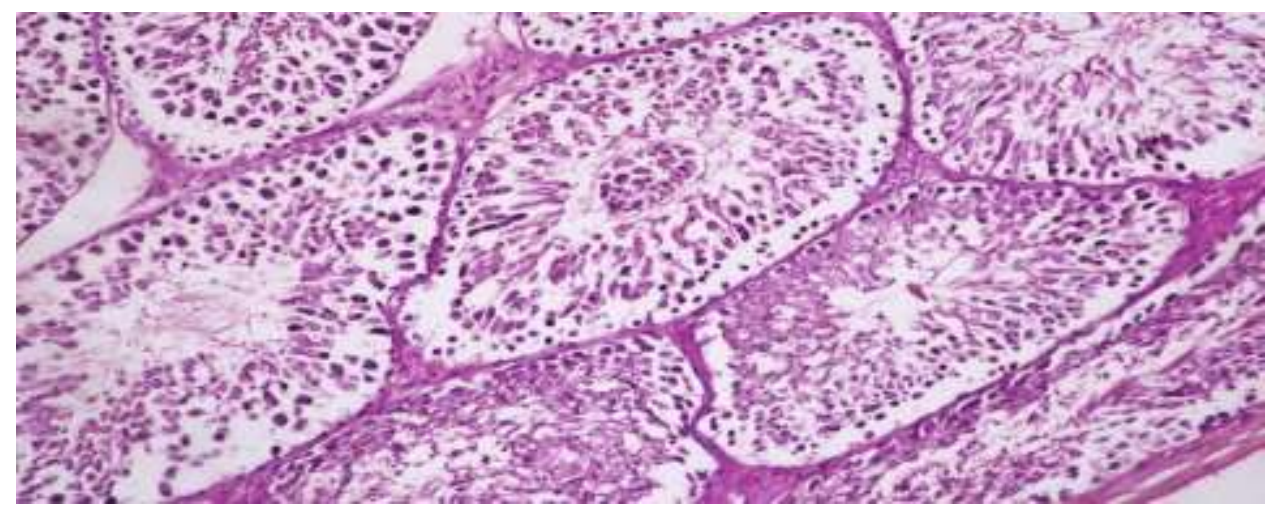

Fig. 12: Testis of Gp.4 chemotherapy alone treated group showing mild testicular degeneration with accumulation of degenerated spermatid in individual tubules. Note, presence of spermatid giant cell.

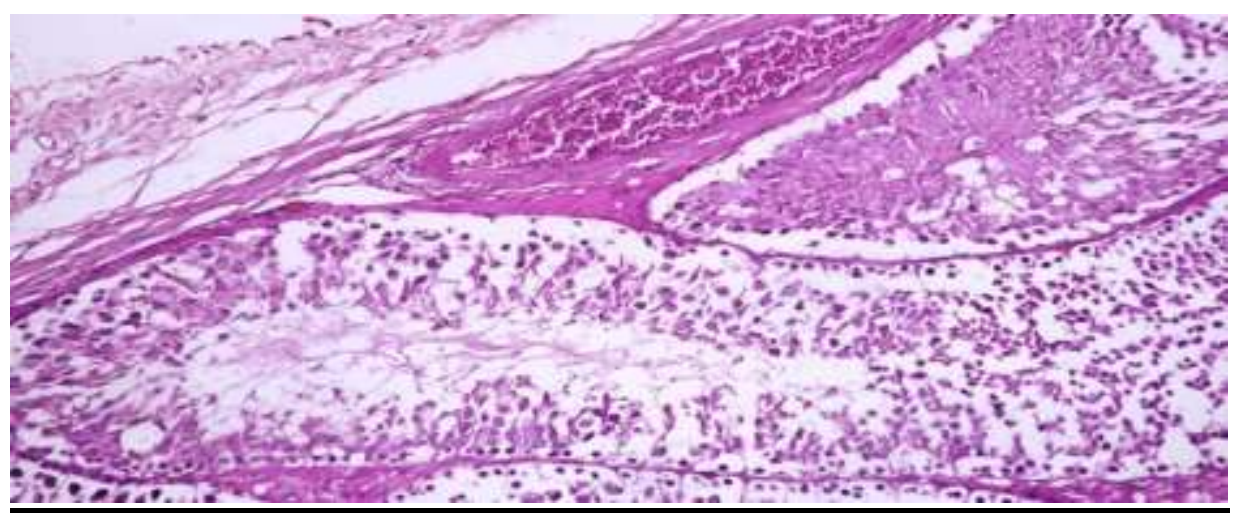

Fig.13: Testis of Gp.4 chemotherapy administrated group characterized by testicular degeneration with accumulation of spermatid coagulum in individual tubules. 


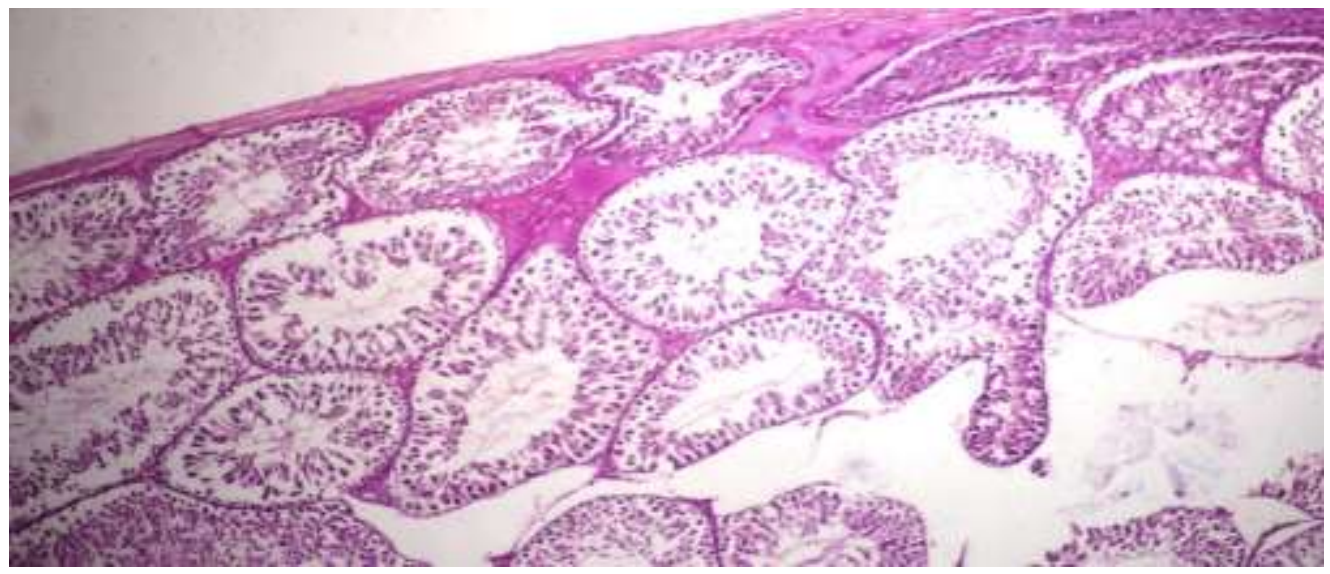

Fig.14: Testis of Gp. 4 chemotherapy administrated group showing interstitial edema in addition to testicular degeneration.

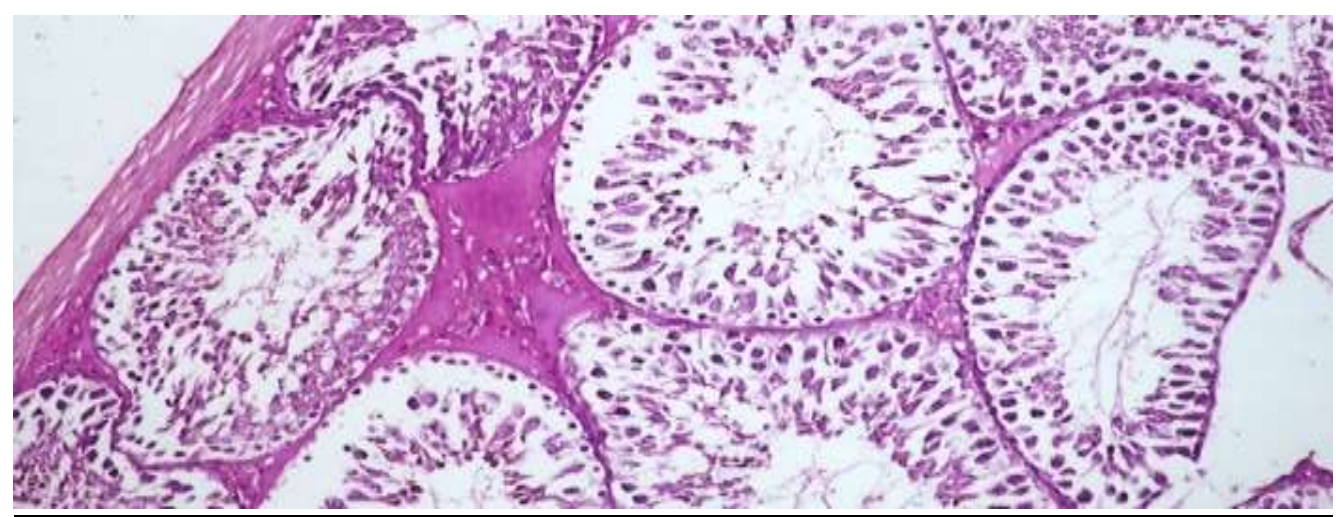

Fig.15: Testis of Gp.4 chemotherapy administrated group showing testicular degeneration and the lumen free of spermatozoa, note interstitial edema.

\section{DISCUSSION}

Cancer is a well-known deadly disease that is caused due to the inability of some uncontrollably growing cells to die. More than 100 types of cancer have been identified till date, classified on the basis of the type of the initially affected cell (Mostofi \& Sesterhenn, 1998). The more dangerous is the malignant ones; occurs when a cancerous cell travel throughout the body by the circulatory system and destroy healthy tissues (Cavallaro and Christofori, 1987). Testicular tumors are the most common genital neoplasms in male consider the third type of male tumor after skin and fibrous tissue tumors (Marko et al., 2014). It represents more than $90 \%$ of male genital tumors and the highest incidence of all animal species (North et al., 2009).
Cancer is treated using a number of techniques that include surgery, chemotherapy, radiation, immunotherapy, gene therapy and hormone therapy (Harris and Levine, 2005).

Nanoscience nowadays is a fast developing field focusing on wide application of different nanomaterials (Ahmad et al., 2003) is considered to be a solving many problems in pharmaceutical sciences and having many potential medical applications (Chen et al., 2008). Drug-releasing nanoparticles used at tumor site to sensitize the cancer cells to chemotherapy in combination with the drug able to track cancer cell death in vivo. The molecular level is extremely important for effective dosing regimens and/or administering novel therapies or combinations (National Cancer Inst., 2017). 
In our experimental study, testicular tumor was found in mice formed large yellowish white mass with hemorrhagic area due to sodium arsenite administration. Testis converted to solid sheet of undifferentiated anaplastic cells with focal necrosis (Fig. 1, 3, 4,5 \& 6). Sodium arsenite group showed reduction in the percentage of seminiferous epithelium and in proportion and volume of Leydig cells. Moreover, there was an increase in the percentage of tunica propria, lumen, lymphatic space, blood vessels, and macrophages. These results are similar to a previous study reported by Grieco et al. (2008). Sodium arsenite has a suppressive influence on spermatogenesis and androgenesis in male reproductive system. It causes testicular toxicity by germ cell degeneration and inhibits androgen production in adult male probably by affecting pituitary gonadotrophins (Kuladip, et al., 2006).

Under microscopic examination, the testis of chemotherapy and copper nanoparticles treated group, showed active spermatogenesis in most seminiferous tubules as well as restoration of germinal epithelium with few intact spaces and minimal injury of testicular tissue (Fig.2, 7, $8,9 \& 10)$. The combination of the copper nanoparticles and chemotherapy made the testis tumor disappear entirely. These results agreed with Hendrik et al. (2020). Cu NPs have the potential to overcome current chemotherapeutic barriers in cancer treatment, because of the nanoscale size and distinctive bioeffects (Laing et al., 2011).

The results of chemotherapy alone treated group showed testicular degeneration with no active spermatogenesis (Fig.11) with presence of spermatid giant cells (Fig.12) and spermatid coagulum in some seminiferous tubules (Fig.13) in addition to testicular edema (Fig. $14 \& 15$ ). This group can be attributed result in obvious clinical signs testicular enlargement in seminiferous tubules. These results agree with Jong et al. (2010). Chemotherapy can be an effective way of treating tumor cells; it can also have adverse effects on healthy cells (Carter, 2019).

Finally, we need further studies to establish a higher testicular tumor in animals. Nanomaterial will be reduce the toxicity of chemotherapeutics and increase their effectiveness. $\mathrm{Cu}$ NPs showed promising anticancer activity against cancer cell. They are an effective pharmaceutical, biomedical, and environmental applications for tumor treatment, also reduce the toxicity and limits the side effect of chemotherapy for multiple tumors.

\section{REFERENCES}

Ahmad, A.; Mukherjee, P.; Senapati, S.; Mandal, D.; Khan, MI.; Kumar, R. and Sastry, M. (2003): Extracellular biosynthesis of Silver nanoparticles using the fungus Fusarium oxyspoRum. Colloids Surf B Biointerf 28:313-318.

Ahmed, K.B.A.; Sengan, M.; Kumar, S. and Veerappan, A. (2016): Highly selective colorimetric cysteine sensor based on the formation of cysteine layer on copper nanoparticles. Sens. Actuators B Chem. 233, 431-437.

Blakeley, B.R. (1987): The effect of Lead on chemical and viral induces tumor production in mice. J. Appl. Toxocol. 7: $167-172$.

Bertrand, C.; Jun, W.; Xiaoyang, X.; Nazila, K. and Omid, C.F. (2014): Cancer Nanotechnology: The Impact of Passive and Active Targeting in the Era of Modern Cancer Biology. Adv. Drug Deliv Rev. 66: 2-25.

Carter, A. (2019): What you need to know about chemotherapy. Medical News J. googlesyndication.com.

Cavallaro, U. and Christofori, G. (2000): Molecular Mechanisms of Tumor Angiogenesis and Tumor Progression. J. Neurooncol. 50 (1-2): $63-70$.

Chen, H.; Roco, MC.; Li, X. and Lin, $Y$. (2008): Trends in nanotechnology patents. Nat Nano; 3: 123-5. 
Chilvers, D.C. and Peterson, P.G. (1987): Global cycling of Arsenic. In Environmental Committee of the problem of Environment (Scope), 31. New York, Jone Willey \& Sons.

Cotchin, E. (1959): Some tumors of dogs and cats of comparative veterinary and human interest. Vet Rec. 71: 1040 1050 .

Gawande, M.B.; Goswami, A.; Felpin, F.X.; Asefa, T.; Huang, X.; Silva, R.; Zou, X.; Zboril, R. and Varma, R.S. (2016): $\mathrm{Cu}$ and $\mathrm{Cu}$-based nanoparticles: synthesis and applications in catalysis. Chem. Rev. 116(6), 3722-3811.

Grieco, V.; Riccardi, E.; Greppi, GF.; Teruzzi, F.; Iermano, V. and Finazzi M. Canine testicular tumours (2008): A study on 232 dogs. J Comp Path. 2008; 138: 86-89.

Grootenhuis, A.J.; Timmerman, M.A.; Hordijk, P.L and Jong, F.M. (1990): Inhibin in immature rate Sertoli cell condition medium: a $32 \mathrm{kDa}$ a -B dimer. Mol. Cell. Endocrinal. 70: 109116.

Harris, S.L. and Levine, A.J. (2005): The p53 Pathway: Positive and Negative Feedback Loops. Oncogene, 18; 24 (17): $2899-908$.

Hendrik, N.; Bella, B.M.; Carla, R.L.; Vasiliki, T.; Yiannis, D.; Johannes, B.; Suman, P.; Lutz, M. and Stefaan J.S. (2020): Model-Based Nano engineered Pharmacokinetics of IronDoped Copper Oxide for Nano medical Applications. Angewandte Chemie International Edition.

Jong, M.C.; Timothy, M.P.; Richard, S.; Luis, A.D. and Michail, A.C. (2010): Disappearing Colorectal Liver Metastases After Chemotherapy: J Gastrointestinal Surg. 14 (11): 1691 700.

Kawakami, K.; Enokida, H. and Tachiwada, T. (2007): Increased SKP2 and CXSI gene expression contributes to the progression of human urethral carcinoma. J Urol 178: 301-307.

Kennedy, PC.; Cullen, JM.; Edwards, JF.; Goldschmidt, MH. and Larsen,
S. (1998): Histological Classification of Tumors of the Genital System of Domestic Animals. WHO Armed Forces Institute of Pathology, Washington DC.

Kuladip, J.; Subarna, J. and Prabhat, K.S. (2006): Effects of chronic exposure to sodium arsenite on hypothalamopituitary-testicular activities in adult rats: possible an estrogenic mode of action. Reprod Biol Endocrinol J. Vol.4; 2006; 4: 9.

Lipowitz, A.J.; Schwartz, A. and Wilson, G.P. (1973): Testicular tumours are rare in the cat and cryptorchidism does not appear to be a risk. Association 34:113-120.

Maeda, H.; Nakamura, H. and Fang, J. (2013): The EPR effect for macromolecular drug delivery to solid tumors: improvement of tumor uptake, lowering of systemic toxicity, and distinct tumor imaging in vivo. Adv. Drug Deliv. Rev; 65: 71-79.

Magrez, A.; Kasas, S.; Salicio, V.; Pasquier, N.; Seo, JW. and Celio, M. (2006): Cellular toxicity of carbon-based nanomaterial's. Nano Lett 2006; 6: 1121-5.

Marko, H.; Branka, A.; Krešimir, S.; Andrea, G.K.; Ana, B.; Ivan-C. S̆.Z. and Željko, G. (2014): Canine testicular tumors: two types of seminomas can be differentiated by immunohistochemistry. BMC Vet. Res. Vol. 10: 169-8.

Martínez, G.F.; Thi, EP.; Silverman, JM.; De Oliveira, CC.; Svensson, SL.; Vanden, Hoek, A.; Sánchez, EM.; Reiner, NE.; Gaynor, EC. and Pryzdial, EL. (2012): Antibacterial activity, inflammatory response, coagulation and cytotoxicity effects of silver nanoparticles. Nanotechnol Biol Med. 8: 328-336.

Matsui, K.; Lo, J.F. and Silver, S. (1999): Molecular Basis for Resistance to Silver nanoparticles. Sci. J. 7: 515534.

Mehata S.C.; Lai, J.C. and Lu, D.R. (2003): Effect of silver nanoparticle 
treatment on the growth profile of plants. Therapy, J. Neurooncol., 62: 47.

Mostofi, F.K. and Sesterhenn, I.A. (1998): World Health Organization International Histological Classification of Tumors. Geneva. 2. Histological typing of testis tumors; pp. 10-12.

National Cancer Inst. (2017): Earlier Detection and Diagnosis. Nano delivery Systems and Devices Branch. Cancer \& Nanotech. National Institutes of Health.

North, S.M.; Manley, C.A.; Leibman, N.F. and Wolchok, J.D. (2009): A retrospective and cross-sectional study of canine tumors. Vet Clin. Small Anim Pract. 26(5): 1155-84.

Pinard, P.; McDaid, H. and Horwitz, S.B. (2018): Antibody-drug conjugates, and various nanoparticle-based

compounds. World J Microbiol Biotechnol, 34(9): 127 - 131.

Snchez-Sanhueza, G.; Fuentes-Rodreguez, D. and Bella-Toledo, H. (2016): Copper nanoparticles as potential antimicrobial agent in disinfecting root canals. A systematic Review. Int. J. Odontostomat., 10(3): 547-554.

Stewart, E. (2017): Mustafa El-Sayed's Nano Scale Fight against Cancer. Eminent Scientist Mustafa El-Sayed to Present at the 254th ACS National Meeting in Washington DC. ACS, Chemical for life. American Chemical Society.

Thamer, N.A. and Barakat, N.T. (2019): Cytotoxic activity of green synthesis copper oxide nanoparticles using aqueous extract on some breast cancer cell lines. Journal of Physics: Conf. Series 1294 (2019) 062104, $1-6.2^{\text {nd }}$. International Science Conference.

Wozniak, B.L.; Ohgaki, H.; Biernat, W. and Peraud, A. (2016): Epidemiological and histopathological analysis of 40 apocrine sweat gland carcinoma in dogs. J. Vet Res 60, 331-337.

$X u, P . ; X u, J . ; L i u, S . ;$ Ren, G. and Yang, Z. (2012): In vitro toxicity of Nano sized copper particles in PC12 cells induced by oxidative stress. J Nano part Res 14: 906 (1-9). 


\section{أستخدام جزيئات النانو للحد من انتثار الخلايا السرطانية في الجهاز التناسلي المسببة لأورام الخصية في الجرزان}

\section{أحمد فتحى ، منح محمد صلحى ، عبل السلام المحمدى ، مبريهان عصام على ، شربين محمود}

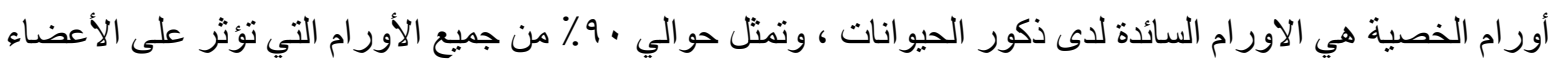

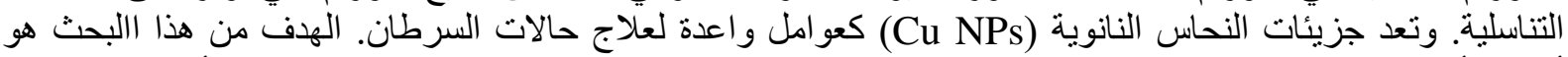

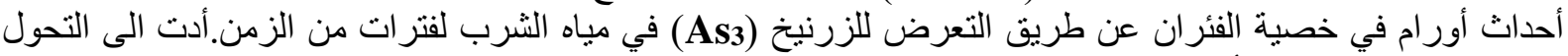

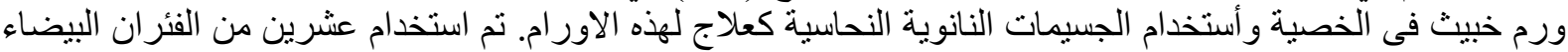

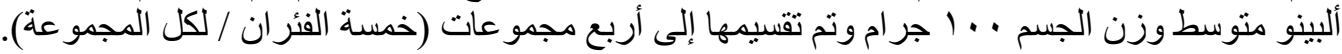

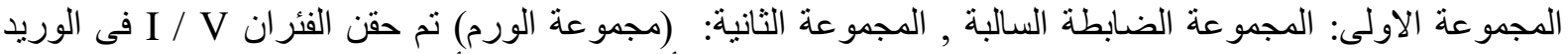

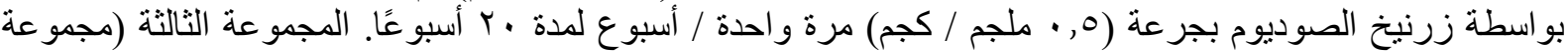

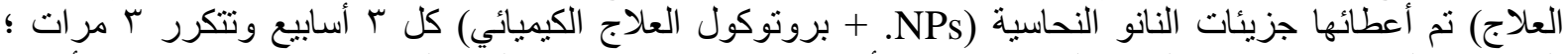
المجموعة الر ابعة (مجموعة العلاج الكيميائي) بدون أستخدام NPs Cuجزيئات النانو النحاسية. وتم جمع عينات النيات الأنسجة

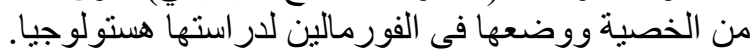

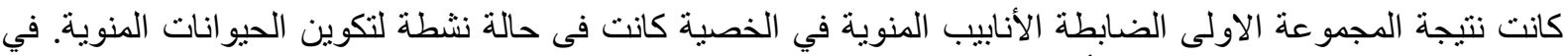

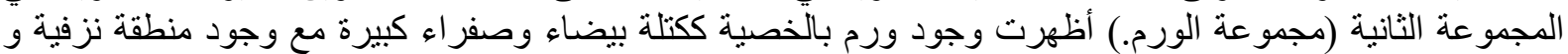

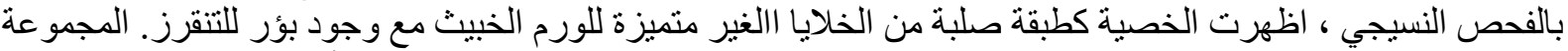

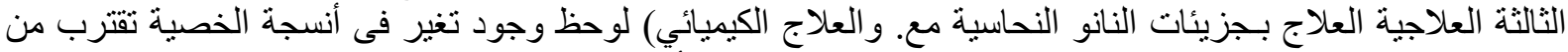

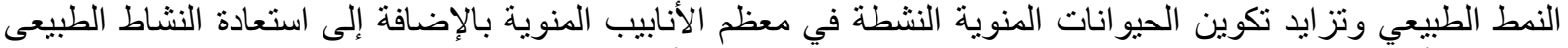

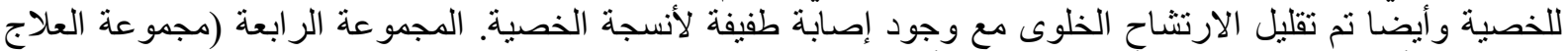

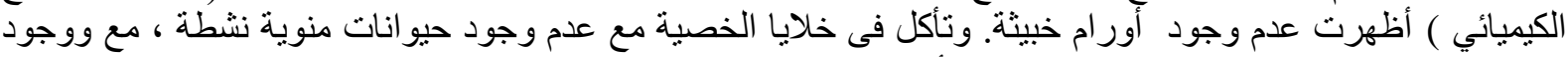
خلايا عملاقة منوية وتجلط خلوى بالإضافة إلى أرتشاح بالخصية.

و أخيرًا ، نحتاج إلى مزيد من الدر اسات عن أسباب أورم الخصية في الحيوانات وأستخدام المو اد النانوية فى العلاج لتقليل من سمية العلاج الكيميائي وزيادة فعاليته. 